\title{
PROBLEMATIKA PEMBELAJARAN SAINS DITINJAU DARI ASPEK GURU
}

\author{
Milya Sari \\ Dosen Fakultas Tarbiyah dan Keguruan IAIN Imam Bonjol Padang \\ e-mail: milyasari.iain@gmail.com
}

\begin{abstract}
Science Education in Indonesia is still poor. There are many components involved in science education such as the teacher. The myriad flaws of the teacher's factor must be addressed: the intake of low teacher, teachers' commitment, performance, the level of teacher education, etc. These are caused by low performance of the principal and the Superintendent and the policies of the Government. To overcome these problems, then, it is necessary to improve the following program including training and tutorial programs, etc. It is expected that through the efforts of increasing teacher's quality will improve students' science literacy.
\end{abstract}

Key words: teacher's problem, science teacher's competence, teacher's quality improvement

Abstrak: Pendidikan sains di Indonesia saat ini masih tergolong rendah. Banyak komponen yang terkait dengan sains dan salah satunya adalah guru. Faktor yang bersumber dari guru mestilah mendapat perhatian serius seperti: rendahnya pengetahuan, komitmen, performa, serta tingkat pendidikan guru. Rendahnya performa guru disebabkan karena kurang berfungsinya tugas dan peran Kepala Sekolah serta kebijakan-kebijakan yang dibuat pemerintah. Oleh karena itu diperlukan pelatihan secara berkala melalui program tutorial, pendidikan professional, dll. Peningkatan kualitas guru pada gilirannya akan bermuara kepada peningkatan keterampilan sains siswa.

Kata Kunci: problematika Guru, kompetensi guru sains, peningkatan mutu guru.

\section{PENDAHULUAN}

Laporan perkembangan sains dan teknologi dari tahun 2005-2010 dalam UNESCO Science Report 2010 di Paris, memperlihatkan Indonesia tidak termasuk negara yang diperhitungkan dalam perkembangan saintek. Ada apa dengan pendidikan saintek kita? Pendidikanlah yang sangat berperan untuk menciptakan SDM yang mengusai saintek tersebut. Sukro Muhab(dalam La tansa, 2010), menyatakan tantangan dunia pendidikan sains di Indonesia di era globalisasi dalam upaya pengembangan saintek adalah kesenjangan kemajuan saintek dengan dunia pendidikan, prestasi pendidikan kita tertinggal dan isu global pendidikan.

Fensham (2008) dalam Unesco Science Report 2008 menyatakan ada sebelas isu penting dalam kebijakan pendidikan sains, yaitu: Issue a: science in schooling and its educational purposes, Issue $b$ : access and equity in science education, Issue $c$ : interest in, and about science, Issue $d$ : how technology relatesto science in education, Issue $e$ : the nature of science and inquiry, Issue f: scientific literacy, Issue g: quality of learning in science, Issue $h$ : the use of ict in scienceand technology education, Issue $i$ : development of relevant and effective assessment in science education, Issue $j$ : science education in the primaryor elementary years, Issue $k$ : professional development of science teachers.

Sebelas issu yang dipaparkan di atas, tujuh diantaranya berkaitan dengan guru. Bagaimana seorang guru sains membuat siswa tertarik belajar sains, bagaimana pembelajaran sains dikaitkan dengan kehidupan sehari-hari, sehingga tujuan utama sains membuat siswa melek sains bisa tercapai. Untuk itu perlu peningkatan kualitas pembelajaran sains termasuk sistem penilaiannya. Untuk memcapai semua itu perlu peningkatan profesionalisme guru.

Profesionalisme guru dalam pembelajaran sains berpengaruh besar terhadap minat 
siswa pada sains. Guru merupakan faktor kunci dalam pembelajaran sains, walaupun ia bukanlah faktor satu-satunya. Karena kinerjanya sangat ditentukan oleh faktor lain, seperti kebijakan pemerintah, kinerja pimpinan dalam hal ini kepala sekolah dan pengawas, dukungan masyarakat dan sebagainya. Berikut ini dibahas secara ringkas bagaimana guru sains yang profesional, masalah guru sains dalam pembelajaran dan penyebabnya serta solusi yang bisa ditawarkan.

\section{GURU SAINS YANG PROFESIONAL}

Menurut PP RI No. 19/2005 tentang Standar Nasional Pendidikan Pasal 28, pendidik/guru adalah agen pembelajaran yang harus memiliki empat jenis kompetensi yakni kompetensi pedagogik, kepribadian, profesional dan sosial. Kompetensi guru dapat diartikan sebagai kebulatan pengetahuan, keterampilan dan sikap yang diwujudkan dalam bentuk perangkat tindakan cerdas dan penuh tanggung jawab yang dimiliki seseorang guru untuk memangku jabatan guru sebagai profesi. Guru yang profesional adalah guru yang memiliki:

a. Kompetensi Kepribadian, yakni kemampuan personal yang mencerminkan kepribadian yang mantap, stabil, dewasa, arif, dan berwibawa, menjadi teladan bagi peserta didik, dan berakhlak mulia.

b. Kompetensi Pedagogik, merupakan kemampuan yang berkenaan dengan pemahaman peserta didik dan pengelola pembelajaran yang mendidik dan dialogis. Secara substantif kompetensi ini mencakup kemampuan pemahaman terhadap peserta didik, perancangan dan pelaksanaan pembelajaran, evaluasi hasil belajar, dan pengembangan peserta didik untuk mengaktualisasikan berbagai potensi yang dimilikinya.

c. Kompetensi Profesional, merupakan kemampuan yang berkenaan dengan penguasaan materi pembelajaran bidang studi secara luas dan mendalam yang mencakup penguasaan substansi isi materi kurikulum matapelajaran di sekolah dan substansi keilmuan yang menaungi materi kurikulum tersebut, serta menambah wawasan keilmuan sebagai guru.

d. Kompetensi Sosial, berkenaan dengan kemampuan pendidik sebagai bagian dari masyarakat untuk berkomunikasi dan bergaul secara efektif dengan peserta didik, sesama pendidik, tenaga kependidikan, orangtua/wali peserta didik, dan masyarakat sekitar.

Rivai dan Murni (2009) menyatakan kriteria guru yang profesional. Menurut mereka guru yang bermutu atau profesional adalah guru yang sejak awal tidak perlu ditatar atau ikut berbagai pelatihan karena dari awal sudah mampu memahami dan menerjemahkan pesanpesan kurikulum dengan cerdas; Mampu mencari, menemukan, dan mengembangkan bahan ajar dan media pembelajaran yang bermutu; Mampu mengembangkan tes dan sistem pengujian yang tepat; dan Terus mengembangkan wawasan utk menunjang profesinya.

Profesionalisme guru perlu dikembangkan secara berkelanjutan. Pengembangan profesionalisme guru berkaitan erat dengan peningkatan mutu pembelajaran. Jika mutu pembelajaran meningkat maka mutu pendidikan menjadi meningkat pula. Artinya, pengembangan profesionalisme guru bertujuan untuk meningkatkan mutu pendidikan. Lufri (2008) menyatakan, banyak bentuk kegiatan yang dapat dilakukan untuk mengembangkan profesionalisme guru, antara lain: melanjutkan pendidikan ke jenjang yang lebih tinggi, pelatihanpelatihan, penataran, seminar, diskusi, atau membina hubungan antara lembaga pencetak guru dan sekolah. Cara terakhir ini bisa ditempuh melalui:

a. Jalur pengabdian pada masyarakat. Melalui jalur ini para dosen dapat mempersiapkan paket-paket khusus berdasarkan kealiannya dan kebutuhan guru dilapangan, ini dapat dilakukan secara berkelanjutan dan berkala.

b. Kerjasama melalui ikatan alumni jurusan, pengembangan profesionalisme guru dapat dijadikan salah satu program kerja, yang dapat dilakukan secara berkala. 
c. Kerjasama melalui penelitian. Bila dosen melakukan penelitian disekolah dengan melibatkan guru sebagai anggota penelitian, sehingga guru mendapatkan pengalaman dalam penelitian yang akhirnya dapat pula mengembangkan dirinya.

Selanjutnya dinyatakan, pengembangan profesionalisme guru bisa juga dilakukan pada lembaga pendidikan (LPTK), pembentukan kemampuan profesional dilakukan melalui dua kegiatan utama, yaitu melalui perkuliahan MKDK dan PBM, dan praktek pendidikan (PPL). Kemampuan profesional harus dikembangkan sepanjang hayat, untuk itu diperlukan pedoman standar pengembangan profesional guru. Di Amerika Serikat melalui National Science Teachers Association (NSTA), 1998 menetapkan standar untuk guru sains (NSTA Standards for Science Teacher Education), meliputi Standard 1: Content, dan Standard 1: Pedagogy. Standard Contentrefers to: Concepts and principles understood through science, Concepts and relationships unifying science domains., Processes of investigation in a science discipline, Applications of mathematics in science research."The NSTA Standards authors define a model of pedagogy familiar to teachers and teacher educators. This model includes: actions and strategies of teaching, organization of classroom experiences, providing for diverse learner needs, evaluation and implementation of learner's prior notions, and transformation of ideas into understandable pieces.

Disamping itu National Science Education Standart (1996) dalam Lufri (2008) memberikan empat standar Program Pengembangan Profesional Guru Sains, yaitu perlu:

1. Standar A. Mempelajari isi sains yang esensial melalui perspektif dan metoda inkuiri.

2. Standar B. Pengetahuan sains yang terintegrasi, belajar, pedagogi, dan para siswa juga memerlukan penerapan pengetahuan terhadap pembelajaran sains.
3. Standar C. Dibangun pemahaman dan kemampuan belajar seumur hidup.

4. Standar D. Koheren dan terintegrasi

\section{PERMASALAHAN DALAM PEMBE- LAJARAN SAINS DARI ASPEK GURU}

Lufri (2011) menyatakan fenomena yang sering terlihat dalam pembelajaran sains adalah: Strategi pembelajaran guru kurang tepat, kurang bervariasi (kurang profesional); Gaya mengajar guru kurang menyenangkan peserta didik; Afeksi guru belum bisa diteladani; Penerapan tugas guru (sebagai pendidik, pengajar dan pelatih) belum berjalan optimal; Kecakapan guru menentukan dan menyajikan materi esensial relatif kurang; Tugas yang terlalu padat bagi anak didik; Mengandalkan LKS yang dijual penerbit tertentu (seharusnya dibuat guru); Kurang menerapkan disiplin bagi anak; Sains disajikan secara teoritis, belum menggunakan laboratorium secara optimal. Ini artinya guru mengajar masih belum profesional, belum bisa menerapkan empat kompetensi yang sudah ditetapkan pemerintah.

Hal senada diungkapkan Syamsuri (2010), hasil survey di kota Malang di kota Malang dari Februari-Maret 2010, terhadap kinerja guru diperoleh beberapa temuan, yaitu: (1) Umumnya para guru masih menyusun KTSP Buku II (silabus, RPP dan LKS) dengan teknik "copy paste", yang berarti mereka belum menyusun silabus, RPP dan LKS berdasar keperluan dan kondisi mereka sendiri; (2) Meskipun mereka mengaku memiliki RPP, namun ketika proses pembelajarannya diobservasi, semua guru tidak membawa RPP dengan berbagai alasan, (3) Dari analisis RPP yang diperoleh ternyata terdapat perbedaan antara apa yang dituliskan dengan apa yang diimplementasikan di kelas, (4) Pengelolaan kelas dilakukan secara konvensional sehingga tidak memungkinkan terjadinya interaksi antar siswa, (5) Dalam melakukan evaluasi/assesmen, umumnya guru menggunakan tes secara tertulis, sehingga tes hanya berorientasi ke ranah kognitif, hanya beberapa guru yang menggunakan rubrik untuk assesmen. Ini berarti bahwa pemahaman guru tentang asesmen hanya pada ranah kognitif, tidak sampai pada ranah afektif dan psikomotor. Hasil survai ini 
menunjukkan juga bahwa tidak ada perbedaan keprofesionalan antara guru sekolah "bermutu" dengan sekolah yang "tidak bermutu". Prestasi siswa sekolah "bermutu" selama ini bukan karena hasil desain pembelajaran gurunya, melainkan karena mutu masukan siswanya yang memiliki nilai (intake) tinggi.

Selanjutnya syamsuri (2010) Dalam rangka meningkatkan mutu guru, Pemerintah telah berupaya maksimal untuk melakukan inservis training dengan menyelenggarakan penataran, pelatihan, workshop dalam beberapa minggu sehingga guru meninggalkan kelasnya, namun setelah kembali ke sekolah para guru tidak menerapkan ilmunya untuk mengefektifkan pembelajaran. Alasan yang sering dikemukakan para guru sebagai berikut: (1) Latar belakang siswa (intake rendah, dari keluarga menengah ke bawah, dari desa/daerah terpencil) yang sulit untuk diajak aktif dan kreatif; (2) Guru tidak memiliki waktu cukup untuk menerapkan metode, pendekatan dan model-model pembelajaran yang disarankan. Jika diterapkan, waktunya lama sehingga guru tidak dapat menyelesaikan penyampaian materi pembelajaran yang cukup banyak kepada siswa; (3) Jika menghadapi UN, guru cenderung mengadakan drill dan latihan soal-soal ujian; (4) Media dan laboratorium tidak mencukupi/tidak ada; (4) Jam mengajar guru terlalu banyak.

Kasus yang sama juga terjadi di Padang (secara khusus) namun hal ini sebenarnya terjadi di Sumatera barat pada umumnya. Hasil penelitian oleh Alberida dkk tahun 2007 (dibahas dalam perkuliahan Problematika Pendidikan MIPA tanggal 29 Maret 2012) bahwa: (1) ditemukan guru-guru SMA Kota Padang membuat RPP secara massal padahal RPP dibuat berdasarkan satuan pendidikan, karena kondisi satu sekolah akan berbeda dengan sekolah lainnya; (2) jika ditinjau ke kelas guru tidak mempunyai RPP, dengan alasan RPP tertinggal di rumah atau RPP tidak ada; (3) ada guru merasa keberatan jika kegiatan belajar mengajarnya di kelas di observasi, karena guru tidak siap di kritik atau tidak mau dikritik, artinya guru tidak mau membuka diri untuk melakukan perubahan, (4) tidak semua guru ikut MGMP dengan alasan materi yang dibahas itu-itu saja, (5) pelatihan oleh LPMP kurang maksimal, karena masih tergantung kepada proyek yang ditetapkan dari pemerintah pusat dan belum maksimalnya kerja sama antara LPMP dengan LPTK sehingga materi pelatihan yang diberikan belum sesuai dengan kebutuhan guru dilapangan.

Sedangkan Yulaelawati (2000) menyatakan problem dan isu dalam pendidikan sains adalah: guru sain kurang kompeten, belum bisa memperlihatkan proses sain dalam pembelajaran di kelas (terutama SD). Masalah secara umum lainnya adalah: Pre-sevice training of teachers\&In-service training menggunakan top-down model sehingga tidak sesuai dengan yang dibutuhkan guru yang kemampuan dan latar belakang yang beragam. Asesmen yang dilakukan guru masih fokus pada penilaian hasil belajar, masih kurang pada penilaian proses. Masih mengutamakan aspek kognitif, afektif dan psikomotor sangat kurang.

Permasalahan guru di Indonesia sangat beragam, jika permasalahan di atas dikelompokkan berdasarkan empat kompetensi guru, maka permasalahan guru sains antara lain: (1) Kompetensi Profesional: kecakapan guru dalam menyiapkan perangkat pembelajaran; kecakapan guru menentukan dan menyajikan materi esensial; masih mengandalkan LKS yang dijual dipasaran, belum membuat bahan ajar sendiri; sains disajikan secara teoritis, belum menggunakan laboratorium secara optimal, (2) Kompetensi pedagogik: strategi yang digunakan kurang tepat; gaya mengajar yang kurang menyenangkan peserta didik; peran sebagai pendidik, pengjar dan pelatih belum optimal; tugas yang terlalu padat kepada peserta didik, (3) Kompetensi sosial/interpersonal: kurang terbuka terhadap kritikan teman sejawat; Kompetensi personal/individu: afeksi guru belum bisa diteladani; kurang menerapkan disiplin bagi anak didik; komitmen, kinerja dan keiklasan dalam merencanakan dan melaksanakan pembelajaran masih kurang.

\section{FAKTOR PENYEBAB TIMBULNYA PERMASALAHAN DALAM PEMBELA- JARAN SAINS DARI ASPEK GURU}


a. Intake (kualitas input) dari calon guru dan kualitas dari LPTK penghasil guru

Rivai dan Murni (2009) menyatakan permasalahan guru saat ini berasal dari input guru yang masuk LPTK. Kenyataan yang terlihat saat ini adalah calon guru berasal dari generasi muda kelas bawah (karena gaji guru rendah) dengan kemampuan yang rendah pula. Jadi, walaupun ikut berbagai pelatihan hasilnya tidak maksimal karena kemampuan dasarnya yang lemah.

Syamsuri (2010) menyatakan tidak semua guru yang ada di sekolah saat ini dihasilkan oleh LPTK berkualitas. Padahal populasi guru yang belum profesional ini lebih besar dibandingkan dengan guru professional alumni LPTK berkualitas. LPTK yang kurang berkualitas itu (tidak mumpuni untuk menghasilkan guru profesional) begitu mudahnya merekrut mahasiswa baru (yang gagal memasuki LPTK bermutu) walau dosen, sarana, prasarana, dan profesionalitasnya tidak dimiliki. Ada Perguruan Tinggi yang menerima 12 kelas (12 kelas dalam satu jurusan dalam bidang (sains) walau hanya memiliki beberapa dosen dan mempercayakan kuliahnya dibina oleh mahasiswa senior. Pada waktu kegiatan kuliah para mahasiswa sepi namun terasa ramai dan semarak ketika wisuda berlangsung. Kapan mereka kuliah? Di mana mereka praktek? Apakah mereka siap menjadi guru sains profesional?

Sejalan dengan kondisi di atas tantangan lain dalam pengembangan profesionalisme guru sains seperti yang dikemukakan Lufri (2008) adalah: guru kurang berpengalaman dalam pekerjaannya; rendahnya komitmen profesional guru dan etos kerjanya serta pengontrolan yang lemah dari pimpinan; minat baca yang rendah untuk mengembangkan diri; budaya mental dalam belajar yang hanya berorientasi pada ijazah dan pangkat; suka mengambil jalan pintas untuk menyelesaikan sesuatu, misalnya menyalin RPP yang sudah ada tanpa menyesuaikan dengan kondisi sekolah tempat dia bekerja, ini semua mempengaruhi kualitas pembelajaran sains di kelas.

b. Manajerial

Lufri (2011) menyatakan, salah satu yang mempengaruhi kinerja guru sains dalam melaksanakan tugasnya berasal dari aspek manajerial; yaitu: Kurangnya perhatian pimpinan terhadap sarana dan prasarana sains (laboratorium dan media); Sulitnya meminta pengadaan alat dan bahan laboratorium; Pelatihan guru belum merata, artinya yang ikut pelatihan orangnya itu-itu juga; Kebijakan sekolah dipengaruhi oleh kepentingan birokrasi; Tidak ada reward bagi guru yang berprestasi dan punishment bagi guru yang kinerjanya jelek; Tidak ada tagihan terhadap pada guru yang sudah mengikuti pelatihan untuk mensosialisasikan dan mengimplementasikan apa yang diperoleh selama pelatihan; dll.

Syamsuri (2010) juga menyatakan Faktor Kepala Sekolah (KS) (juga Pengawas, DIKNAS) memiliki hubungan komando yang tegas dalam menentukan bentuk kegiatan guru di kelas. Hasil uji kompetensi yang dilakukan oleh Dirjen PMPTK menunjukkan bahwa $70 \%$ dari $250.000 \mathrm{KS}$ tidak kompeten, terutama di bidang manajerial dan supervisi, sebagai kompetensi yang paling menentukan kualitas pendidikan. Mengapa hal ini terjadi? Jawabannya karena perekrutan KS tidak dilakukan berdasarkan keprofesionalan mereka sesuai dengan ketentuan, melainkan berdasar faktor-faktor lain, misalnya faktor politik. Sejak diberlakukannya otonomi daerah, pengangkatan KS (juga DIKNAS Kabupaten/Kota) ditentukan oleh Bupati atau Walikota. Dalam kondisi demikian, para guru melakukan pembelajaran di kelas tanpa adanya supervisi yang memadai. Pengangkatan KS yang ditentukan oleh Bupati atau Walikota membuat idealisme guru menjadi menurun. Guru yang krtitis tidak bisa muncul, karena kritikan yang tidak disukai pimpinan akan menyebabkan mereka dimutasi. Kondisi ini 
membuat guru tertekan dalam bekerja sehingga kinerjanya menjadi lemah.

c. Fasilitas Laboratorium, perpustakaan dan sarana prasarana lainnya

Rendahnya kompetensi KS dapat dilihat dari keberadaan Laboratorium dan Perpustakaan Sekolah. Laboratorium ada tetapi terbatas, peralatan dan bahan tidak lengkap, sementara di dalam perpustakaan yang ada hanyalah buku yang digunakan guru dalam proses pembelajaran. Tidak ada pilihan buku yang ditawarkan kepada siswa yang dapat digunakan sebagai sumber belajar. Kebijakan Pemerintah tentang pengadaan buku cenderung mengarahkan sekolah untuk memiliki buku seragam, tanpa variasi yang memadai.Yulaelawati (2000), menyatakan rendahnya kinerja guru disebabkan karena faktor : Laboratorium belum memadai; Ada laboratorium dengan peralatan mahal tetapi belum dimanfaatkan secara optimal karena keterbatasan kemampuan guru mengoperasikan alat; dan karena kurikulum lebih mengutamakan sain secara teoritis.

Rendahnya kemampuan/kinerja guru dalam kegiatan laboratorium disebabkan oleh berbagai hal. (1) rendahnya skill guru, karena memang kurangnya kegiatan di laboratorium dari LPTK menghasil gurru tersebut, (2) penghargaan KS yang kurang kepada guru sains yang ditandai dengan kurangnya insentif bagi guru sains yang mengadakan kegiatan praktikum dan penyamaan beban kerja antara guru IPA dengan IPS, (3) pemahaman guru sains yang rendah terhadap urgensi laboratorium dalam pembelajaran IPA.

Untuk sarana fisik banyak sekali sekolah dan perguruan tinggi kita yang gedungnya rusak, kepemilikan dan penggunaan media belajar rendah, buku perpustakaan tidak lengkap. Sementara laboratorium tidak standar, pemakaian teknologi informasi tidak memadai dan sebagainya. Bahkan masih banyak sekolah yang tidak memiliki gedung sendiri, tidak memiliki perpustakaan, tidak memiliki laboratorium dan sebagainya.

d. Kualitas buku pelajaran sains yang digunakan guru.

Guru belum bisa membuat bahan ajar sendiri dan memilih materi-materi esensial dari mata pelajarannya. Pembelajaran tergantung kepada buku teks yang digunakan sekolah. Banyak buku teks sains saat ini memberikan penekanan berlebihan pada fakta ilmiah dan formula matematis sedangkan hubungan konsep-konsep sains dengan pengalaman atau fenomena alam sehari-hari, banyak tidak dijelaskan.

Adisendjaja (2010) melakukan penelitian terhadap buku ajar biologi kelas X.Hasil penelitian menunjukkan bahwa tema literasi sains yang paling banyak muncul pada buku ajar yang dianalisis adalah Pengetahuan sains yakni sebesar $82 \%$, Penyelidikan hakikat sains sebesar $2 \%$, Sains sebagai cara berpikir sebesar $8 \%$ dan Interaksi sains, teknologi dan masyarakat sebesar $8 \%$. Dengan demikian dapat disimpulkan bahwa buku ajar Biologi yangdianalisis lebih menekankan pada pengetahuan sains, yakni menyajikan fakta, konsep, prinsip,hukum, hipotesis, teori, model dan pertanyaan-pertanyaan yang meminta siswa untuk mengingat pengetahuan atau informasi, jadi masih pada aspek kognitif tingkat rendah..

e. Ijazah/tingkat pendidikan guru

Sebagian guru di Indonesia dinyatakan tidak layak mengajar. Hamid (2010) memaparkan, Persentase guru menurut kelayakan mengajar dalam tahun 2002-2003 adalah: untuk SD yang layak mengajar hanya $21,07 \%$ (negeri) dan $28,94 \%$ (swasta), untuk SMP 54,12\% (negeri) dan 60,99\% (swasta), untuk SMA 65,29\% (negeri) dan 64,73\% (swasta), serta untuk SMK yang layak mengajar 55,49\% (negeri) dan 58,26\% (swasta). Untuk 2009/2010,dapat dilihat pada Tabel. 1 dan 2 berikut ini. 
Tabel 1. Persentase guru layak mengajar terhadap guru*) Tahun 2009/2010

\begin{tabular}{c|c|c|c}
\hline \multirow{2}{*}{ TINGKAT } & \multicolumn{2}{|c|}{ GURU } & \multirow{2}{*}{$\%$} \\
\cline { 2 - 3 } & JUMLAH & LAYAK & \\
\hline SMP & 638.014 & 556.998 & 87.30 \\
\hline SMA & 327.163 & 262.597 & 80.26 \\
\hline
\end{tabular}

Sumber: Pusat Statistik Pendidikan, Balitbang- Kemendiknas Tahun 2009/2010

Tabel 2. Perkembangan persentase guru layak mengajar terhadap guru*) seluruhnya

\begin{tabular}{|c|c|c|c|c|c|c|c|c|}
\hline \multirow{3}{*}{ TINGKAT } & \multicolumn{2}{|c|}{ Tahu } & \multicolumn{6}{|c|}{ : 2006/2007--2009/2010 } \\
\hline & \multicolumn{2}{|c|}{20062007} & \multicolumn{2}{|c|}{20072008} & \multicolumn{2}{|c|}{$2008 / 2009$} & \multicolumn{2}{|c|}{20092010} \\
\hline & JUMLAH & $\%$ & JUMLAH & $\%$ & JUMLAH & $\%$ & JUMLAH & $\%$ \\
\hline SMP & 487.512 & 78.04 & 536.416 & 86.26 & 550.406 & 87.50 & 556.998 & 87.30 \\
\hline SMA & 215.722 & 75.48 & 237.094 & 77.52 & 250.270 & 76.61 & 262.597 & 80.26 \\
\hline
\end{tabular}

Sumber: Pusat Statistik Pendidikan, Balitbang- Kemendiknas Tahun 2009/2010

Catatan/Notes :

Guru layak mengajar adalah guru yang berijazah Diploma III/Sarmud Keguruan dan ijazah di atasnya

*) Termasuk Kepala Sekolah

Kelayakan mengajar berhubungan dengan tingkat pendidikan guru itu sendiri. Data Balitbang Depdiknas (dalam Hamid, 2010) menunjukkan dari sekitar 1,2 juta guru SD/MI hanya 13,8\% yang berpendidikan diploma D2-Kependidikan ke atas. Selain itu, dari sekitar 680.000 guru SLTP/MTs baru 38,8\% yang berpendidikan diploma D3-Kependidikan ke atas. Pada tingkat sekolah menengah, dari 337.503 guru, baru $57,8 \%$ yang memiliki pendidikan $\mathrm{S} 1 \mathrm{ke}$ atas. Pada tingkat pendidikan tinggi, dari 181.544 dosen, baru $18,86 \%$ yang berpendidikan $\mathrm{S} 2$ ke atas $(3,48 \%$ berpendidikan S3). Tahun 2009/2010 Jumlah guru menurut ijazah tertinggi dapat dilihat pada Tabel 3. berikut ini:

Tabel 3. Jumlah Guru Menurut Ijazah Tertinggi di Indonesia

\begin{tabular}{|c|c|c|c|c|c|c|c|c|c|c|}
\hline \multicolumn{5}{|c|}{$\begin{array}{l}\text { status } \\
\text { tahun }\end{array}$} & \multicolumn{6}{|c|}{$\begin{array}{l}\text { : negeri+swasta } \\
\text { :2009/2010 }\end{array}$} \\
\hline \multirow[b]{2}{*}{ SEKOLAH } & \multicolumn{2}{|c|}{ SLTA } & \multirow{2}{*}{ PGSL. } & \multirow{2}{*}{$\begin{array}{c}\text { PGSLA } \\
\text { D2 }\end{array}$} & \multicolumn{2}{|c|}{ Diploms } & \multicolumn{2}{|c|}{ Sariana } & \multirow{2}{*}{$\begin{array}{l}\text { Pasca } \\
\text { Sarjena }\end{array}$} & \multirow[b]{2}{*}{ TOTAL: } \\
\hline & Keggurana & $\begin{array}{l}\text { Non } \\
\text { Keggunan }\end{array}$ & & & Kequinan & $\begin{array}{l}\text { Bulkan } \\
\text { kequnuan }\end{array}$ & Kegunana & $\begin{array}{l}\text {.on } \\
\text { keggunan }\end{array}$ & & \\
\hline SD & 212522 & 99.349 & 19.410 & 730.167 & 28.284 & 10.974 & 331.500 & 32301 & 26.69 & 1.487 .126 \\
\hline SNP & . & . & 47.393 & 32719 & 54999 & 12826 & 422154 & 29.500 & 8.653 & 608.164 \\
\hline SMA & . & . & 7840 & 5189 & 20.699 & 6916 & 244.646 & 23.499 & 8.376 & $36.15:$ \\
\hline
\end{tabular}

Sumber: Pusat Statistik Pendidikan, Balitbang- Kemendiknas Tahun 2009/2010

Data statistik juga menunjukkan dari total jumlah guru sekitar 2,4 juta orang, sebagian besar berlatar belakang pendidikan SLTA dan D3 untuk jenjang TK-SDSMP, dan sebagian kecil tamatan S1 untuk jenjang SMA. Tentu saja ini berpengaruh pada kemampuan mengajar, yang diukur dengan penguasaan materi pelajaran dan metodologi pengajaran. Selain itu, banyak guru yang mengajar di luar bidang keahliannya, yang secara teknis disebut mismatch. Contoh ekstrem, guru sejarah mengajar matematika dan SAINS, yang terutama banyak dijumpai di madrasah (MI, MTs, MA). Guru mismatch ini jelas tidak mempunyai kompetensi untuk mengajar mata pelajaran yang bukan bidang keahliannya sehingga dapat menurunkan mutu aktivitas pembelajaran.

f. Rendahnya Kesejahteraan Guru

Rendahnya kesejahteraan guru mempunyai peran dalam membuat rendahnya kualitas pendidikan Indonesia. Berdasarkan survei FGII (Federasi Guru Independen Indonesia) pada pertengahan tahun 2005, idealnya seorang guru menerima gaji bulanan serbesar Rp 3 juta 
rupiah. Sekarang, pendapatan rata-rata guru PNS per bulan sebesar Rp 1,5 juta. guru bantu Rp, 460 ribu, dan guru honorer di sekolah swasta rata-rata Rp 10 ribu per jam. Dengan pendapatan seperti itu, terang saja, banyak guru terpaksa melakukan pekerjaan sampingan. Ada yang mengajar lagi di sekolah lain, memberi les pada sore hari, menjadi tukang ojek, pedagang mie rebus, pedagang buku/LKS, pedagang pulsa ponsel, dan sebagainya (Republika, 13 Juli 2005, (dalam Hamid, 2010)).

Adanya UU Guru dan Dosen, barangkali kesejahteraan guru dan dosen (PNS) agak lumayan. Pasal 10 UU itu sudah memberikan jaminan kelayakan hidup. Pada pasal itu disebutkan guru dan dosen akan mendapat penghasilan yang pantas dan memadai, antara lain meliputi gaji pokok, tunjangan yang melekat pada gaji, tunjangan profesi, dan/atau tunjangan khusus serta penghasilan lain yang berkaitan dengan tugasnya. Mereka yang diangkat pemkot/pemkab bagi daerah khusus juga berhak atas rumah dinas (Pikiran Rakyat, 9 Januari 2006, (dalam Hamid, 2010)).

\section{g. Kebijakan pemerintah}

1. Peningkatan mutu guru tergantung proyek.

Pemerintah telah melakukan berbagai upaya untuk meningkatkan mutu pendidikan di Indonesia, mulai dari upaya pengubahan kurikulum (sekarang berlaku KTSP), peningkatan guru (penataran, seminar, pelatihan), manajemen sekolah, melengkapi media, laboratorium (sarana, prasa-rana), hingga ke penerbitan payung hukum dalam peningkatan mutu pendidikan dengan dikeluarkannya UU No 14 tentang Guru dan Dosen, serta Peraturan Pemerintah No. 19 Tahun 2005 tentang Standar Nasional Pendidikan. Untuk menyukseskan upaya peningkatan mutu pendidikan tersebut, Pemerintah melakukan kerjasama dengan berbagai negara.
Namun kerjasama tersebut umumnya kurang berarti dalam meningkatkan kualitas pendidikan di Indonesia. Hasilhasil survai menunjukkan bahwa kualitas pendidikan di Indonesia masih rendah. Biasanya, para guru bersemangat ketika "proyek" berlangsung, namun mereka akan kembali ke kebiasaan aslinya ketika "proyek" itu usai. Ini disebabkan belum dilaksanakannya pembinaan guru secara tetap/periodik, sehingga guru belajar sepanjang hayat seperti di Negara Jepang.

Disamping itu peran LPMP masih belum jelas,semua kegiatan masih tergantung proyek dan kerja sama dengan LPTK penghasil guru belum maksimal. Sebagai "bengkel" dari produk yang dihasilkan LPTK, seharusnya LPMP dan LPTK saling memberi informasi tentang apa yang dibutuhkan guru dilapangan berdasarkan masalah yang dihadapi, sehingga kurikulum yang ditawarkan LPTK dan pelatihan yang diberikan LPMP menjadi bermanfaat bagi guru/calon guru yang mengikutinya.

2. Ujian Nasional Membelenggu Guru

Faktor Kebijakan Pemerintah yang cukup mengganggu proses pembelajaran adalah Ujian Nasional (UN). Menjelang UN, semua perhatian sekolah tertuju pada persiapan menghadapi UN. Para guru yang biasanya aktif di MGMP menjadi tidak aktif. Mereka sibuk mengadakan dril dan latihan menyelesaikan soal untuk para siswanya. Tindakan guru sebelum UN, melakukan dril dan latihan penyelesaian soal. Dril dan latihan soal bukanlah upaya pembelajaran siswa dan tidak mendidik pendidikan. Siswa hanya disuruh menghafal fakta-fakta dalam ilmu melalui dril, padahal kemampuan seseorang menghafal ada batasnya. 
Soal-soal dalam UN yang hanya berupa soal kognitif tidak banyak mengungkap apa saja yang dilakukan siswa ketika belajar di laboratorium dan menggunakan media. Di kelas para guru melatih siswa melakukan pengamatan, menganalisis, merumuskan hipotesis, melakukan eksperimen, tetapi soal-soal UN tidak pernah mempermasalahkannya. Akibatnya para guru enggan untuk melatih siswa berkegiatan karena soal UN tidak pernah beranjak dari hafalan di buku? Akhirnya guru kembali ke pola lama: berceramah, menyajikan semua materi yang banyak agar target tercapai dan melakukan drill untuk para siswanya.

3. Beban kerja guru 24 jam seminggu yang memberatkan

Masalah lain yang muncul dari kebijakan sertifikasi adalah beban kerja guru yang dinilai memberatkan. Beban kerja yang tinggi membuat guru kurang mempunyai waktu untuk mempersiapkan pembelajarannya, ini membuat kualitas pembelajaran jadi menurun. Idealnya penilaian 24 jam tersebut berdasarkan kinerja, dimana kegiatan guru tidak hanya dinilai dari jumlah jam mengajar dikelas, tetapi kegiatannya dalam mempersiapkan perangkat pembelajaran, penelitian, bahan ajar juga jadi pertimbangan. Namun masalahnya siapa yang akan menilai kerja guru tersebut?

\section{USAHA-USAHA PENINGKATAN MUTU GURU SAINS}

Setiap usaha peningkatan kualitas pendidikan akan berarti apabila melibatkan guru. Karena dalam sistem pendidikan, guru merupakan kunci dan berada pada titik sentral dari setiap reformasi pendidikan. Mengingat peran guru yang strategik maka perlu dilakukan upaya-upaya memperbaiki mutu guru. Usahausaha tersebut antara lain:

1. Memperbaiki mutu calon guru dan mutu LPTK serta menetapkan standar guru sains
Rivai dan Murni (2009) menyatakan permasalahan guru saat ini berasal dari input guru yang masuk LPTK. Tindakan yang perlu dilakukan supaya guru bermutu adalah: gaji guru ditinggikan, Jabatan guru dievaluasi secara periodik, karir guru jelas, seleksi calon guru harus ketat, dan Hanya LPTK bermutu yang boleh menyelenggarakan pendidikan guru sesuai dengan standar yang sudah ditetapkan.

Jika calon guru yang masuk sudah punya komitmen yang tinggi terhadap profesinya, gaji kecil atau keterbatasan alat tidak menjadi kendala dalam mendidik siswanya. Seperti yang terjadi di SDN 8 Langkahan (Aceh Utara), seorang guru honorer di daerah terpencil, jarang mengikuti training guru, buku referensi hampir jarang ditemukan, dan sedikitnya supervisi dari kepala sekolah. Namun guru ini berhasil membuat media yang bisa membantu siswa memahami konsep gaya, dari bahan yang sangat sederhana. Orisinalitas gagasan dan kreativitas meracik bahan baku pembuatan media merupakan bukti bahwa kreativitas tidak ditentukan oleh fasilitas, tapi oleh komitmen atau ikhtiar dari guru itu sendiri untuk menjadi guru yang baik. (Sapa'at. 2012).

2. Merubah paradigma pendidik

Tuntutan era globalisasi yang harus dijawab oleh dunia pendidikan adalah Kompetisi Global. Sukro Muhab (dalam La Tansa, 2010) menyampaikan beberapa tuntutan dunia global yang harus dijawab oleh dunia pendidikan. Paradigma yang secara teoritik dan praktik sudah dilakukan di sekolah-sekolah yang dinilai mampu menjawab tantangan global. Paradigma tersebut dapat sebagai berikut:

a. Sistem pendidikan yang saat ini lebih memprioritaskan kemampuan kognitif hafalan, sepatutnya diarahkan penguasaan pengetahuan dan kompetensi bidang studi.

b. Sistem pendidikan yang saat ini lebih mengarahkan keterampilan mekanistik, sepatutnya diarahkan ke arah pem- 
bekalan life skill, pola pikir kreatif dan inovatif

c. Sistem pendidikan yang saat ini kurang memperhatikan nilai, sepatutnya diarahkan ke arah pembentukan sikap mulia terhadap diri sendiri, orang lain, lingkungan, bermoral dan beretos kerja.

d. Sistem pendidikan yang saat ini kurang memperhatikan metode pembelajaran interaktif, sepatutnya diarahkan bagaimana membentuk hubungan yang interaktif, dialogis dan terbuka dalam proses belajar .

3. Melakukan dampingan/pelatihan terhadap guru secara berkelanjutan. Di samping adanya pola diklat berjenjang seperti Kelompok Kerja Guru, Musyawarah Guru Mata Pelajaran, dan pelatihan guru oleh LPMP, ada beberapa cara yang bisa dilakukan:

a. Lesson Study (Syamsuri, 2010). Lesson Study, guru berkolaborasi dengan guru, dibimbing oleh dosen pendamping bagaimana menyusun RPP, LKS yang efektif dan membelajarkan siswa. Hasilnya, yakni RPP dan LKS tersebut, diimplementasikan ke dalam proses pembelajaran di kelas dengan menun-juk salah seorang sebagai guru model dan guru lain bertindak selaku observer. Guru membelajarkan siswa berpedoman kepada RPP yang telah disusun bersama. Observer tidak mengamati guru, melainkan mengamati siswa. Apakah siswa benar-benar belajar. Semua observer mengungkapkan temuannya dan jalan keluar yang disarankan akan dipergunakan untuk merevisi RPP. RPP hasil revisi dapat diterapkan untuk proses pembelajaran di kelas lain. Demikian seterusnya.

b. Decentralized Basic Education Three (DBE3)

Proyek Decentralized Basic Education Three (DBE3) adalah proyek lima tahun yang dirancang oleh USAID
Indonesia untuk menunjang peningkatan pendidikan dasar terdesentralisasi yang bermutu dan relevan di Indonesia. Sejak tahun 2005 DBE3 telah melatih lebih dari 7.000 guru dari 196 sekolah formal, dengan menitikberatkan pada pengembangan keterampilan siswa. Hal ini dilakukan dengan cara: Membantu guru-guru sekolah lanjutan pertama dalam meningkatkan proses belajar dan mengajar; Menyediakan sumber informasi dan bahan pembelajaran bagi guru-guru untuk menunjang proses pembelajaran, dan Membantu perbaikan sistem pelatihan guru dan calon guru di tingkat nasional agar lebih praktis dan bermutu.

\section{SIMPULAN}

Dari uraian sebelumnya dapat ditarik beberapa kesimpulan pertama, adanya permasalahan dalam pendidikan sains di Indonesia, yaitu pembelajaran sains belum diajarkan sebagaimana mestinya. Kedua, Faktor utama terjadinya kondisi tersebut adalah rendahnya mutu guru yang mengajarkan sains di sekolah. Rendahnya mutu guru ini terlihat dari rendahnya kinerja yang ditunjukkan guru dalam melaksanakan tugasnya. Penyebab timbulnya permasalahan ini antara lain adalah rendahnya mutu calon guru yang masuk LPTK dan rendahnya mutu LPTK yang menghasilkan guru. Disamping itu kinerja pengawas juga kurang maksimal, dan kebijakan pemerintah banyak yang tidak memihak kepada guru. Ketiga, Langkah-langkah yang perlu dilakukan adalah pembenahan mutu guru melalui perbaikan input calon guru dan hanya LPTK bermutu yang boleh melaksanakan pendidikan guru. Untuk guru-guru yang sudah bertugas perlu ditingkatkan kesejahteraannya, dan kompetensinya melalui berbagai program, dalam bentuk lesson study, Better Teaching and Learning (BTL), atau program lainnya. Akhirnya dari kegiatan ini adalah meningkatnya kualitas pembelajaran yang bisa meningkatkan kualitas pendidikan. Semoga.

\section{DAFTAR RUJUKAN}


Adisendjaja, Yusuf Hilmi. 2010. Analisis Buku Ajar Biologi SMA kelas X di kota Bandung berdasarkan Literasi Sains. Di Akses 3 Maret 2012

Baiquni, Achmad. 1997. Al Qur'an dan Ilmu Pengetahuan Kelaman. Jakarta: Dana Bhakti Prima Yasa.

Decentralized Basic Education Three (DBE3). 2011. Newsletters. Jakarta, Edisi BI Final. No 11 September 2011. Tersedia di www.inovasipendidikan.net. Diakses 22 Januari 2012

Hamid, Huzaifah. 2010. Ciri-ciri dan masalah pendidikan indonesia. Tersedia di Biologo Online, Blog Pendidikan Biologi.

http://zaifbio.wordpress.com/2010/01/. Diakses 3 Maret 2012.

La Tansa. 2010. Visi pendidikan global. Tersedia di: http://www.pesantrenlatansa.sch.id/ index.php /opini. Diakses 3 Maret 2012

Lufri. 2008. Pendidikan \& Pembelajaran Biologi Bernuansa IESQ. Padang: UNP Press.

Lufri. 2011. Problematik Pendidikan MIPA. (Bahan Kuliah S3, Problematik Pendidikan MIPA. Prodi Ilmu Pendidikan, konsentrasi Pendidikan MIPA. PPs UNP). Tidak dipublikasikan.

National Science Teacher Association (NSTA). 1998. NSTA Standards for Science Teacher Education USA. (dalam Mark Enfield, Michigan State University)

Pusat Statistik Pendidikan, Balitbang Kemendiknas. Statistik pendidikan SD, SMP, SMA 2009-2010. Tersedia di akses 13 maret 2012

Rivai, Veithzal\& Murni, Sylviana. 2009. Teori Management Analisis Teori \& Praktek. Jakarta: Raja Grafindo Perkasa.
Sapa'at, Asep. 2012. Mudahnya Jadi Guru Kreatif. Tersedia di Republika online. www.republika.co.id. Diakses 16 Januari 2012.

Syamsuri, Istamar. 2010. Peningkatan Kompetensi Guru Untuk Meningkatkan Minat Siswa Pada Bidang MIPA. (makalah disampaikan dalam lokakarya MIPAnet 2010, The Indonesian Network Of Higher Educations Of Mathematics And Nanutal Sciences, tanggal 26-27 Juli 2010, di IPB, Bogor).

Unesco. 2008. Science Education PolicyMaking. Eleven Emerging Issues. By Peter J.Fensham. Tersedia di www.unesco.org. Di akses 29 Januari 2012.

Unesco. 2010. The Growing Role of Knowledge in The Global Economy. By Hugo Hollanders and Luc Soete. Tersedia di www.unesco.org. Di akses 29 Januari 2012.

Yulaelawati, Ella. 2000. Indonesia. (dalam Science Education For Contemporary Sociaty: Problems, Issues and Dilemas. Final Report of The Internatinal Workshop on The Reform in The Teaching of Science and Technology at Primary and Seconderary Level in Asia: Comparative References to Europe. Beijing, 27 - 31 March 2000. Edited by Muriel Poisson. 